\title{
The Recent Changes to the Legal Regime of the Foreign Investments in the Fuel and Energy Sector of Russia
}

\author{
Rashad A. Kurbanov \\ Doctor of Law, Professor, Honored Lawyer of the Russian Federation, Head of the Secretariat of the Delegation of the Russian \\ Federation at the European Commission for Democracy through Law (Venice Commission) at the Institute of Legislation and \\ Comparative Law under the Government of the Russian Federation, Head of the Civil Law and Procedure Department at the \\ Russian University of Economics named after G.V. Plekhanov; Email: mos-ssp@mail.ru
}

\section{Doi:10.5901/mjss.2015.v6n5s2p79}

\section{Abstract}

Approved by the Government of the Russian Federation's the Energy strategy till 2030 notes that the production of fuel energy, according to the strategy, will continue to grow, in particular through the development of new fields in Eastern Siberia and in the Far East, including beyond the Arctic Circle in the Arctic region. It is expected that by 2030 Russia will produce 880-940 billion cubic meters of gas and about 530-535 million tons of oil per year. Modern international experience shows that the proper condition and functioning of the fuel and energy complex is possible only by investing in this sphere of the significant investment and the availability of relevant government and regulatory policies, and well-chosen tactics of investors attracting can contribute to sustainable development and growth of innovative competitiveness indicators. The key point to attract the major investments is the availability of an appropriate regulatory frameworks. There are the basic legislative acts governing this field with their recent changes in the present article.

Keywords: investment, oil and gas sector, legal framework, Russian Federation, oil and gas production, law, tax, government policy, constitution, foreign investments, subsoil

Oil and gas industry is strategically important not only for the Russian Federation. Russian energy resources are exporting in many countries, including European countries. Stable functioning and development of this sector of the Russian economy is largely dependent on investments, including foreign investments. In this context the legal regime of foreign investments is of utmost importance that determines the relevance of the research in this article.

To achieve this goal have been used and the general scientific specific scientific methods: formal-legal method, legal methods of modeling and forecasting. Also, the study used dialectical, historical, logical, comparative method and system-structural analysis.

Norms of the Constitution of Russian Federation ${ }^{1}$ (hereinafter - «the Constitution») as a base of the legal regime of the foreign investment in Russian fuel-energy sector are of special attention in our research.

As it was mentioned in Russian legal doctrine, «...the constitutional principles are not invented by the people, but are the subject to disclosure by them as well as all principles which exist objectively»². First of all it is true for art. 8 of the Constitution, which guarantees the unity of the economical space, free movement of goods, services and financial instruments, the maintenance of the competition, and the freedom of economical activity.

Being the principal provisions of the market economy and entrepreneurship, these norms are the basis for the investment activity in Russia.

The part 2 art. 8 of the Constitution, enshrines the pluralism of the forms of property and it's equal defense. It was developed in the art. 9 of the Constitution stipulates the regulations on the land and other natural resources.

The provisions of the Constitution are developed in the special norms of legislation.

According to the part 4 of the art. 15 of the Constitution, the commonly recognized principles and norms of the international law and the treaties of Russian Federation form the integral part of its legal system. The treaties of Russian Federation prevail the federal laws and other legal acts.

The Constitution stipulates guarantees of the investment activity as well.

The art. 34 of the Constitution guarantees the right to free use of his abilities and assets for commercial and other

${ }^{1}$ Adopted on the referendum of 12.12.1993 // Collected Legislation of the Russian Federation, 26.01.2009, №4, art.445.

${ }^{2}$ Gadzhiev G.A. The Constitutional principles of the market economy (the development of the basement of the civil law in the decisions of the Constitutional Court of Russian Federation) - M., 2002. - P. 51. 
activity which is not prohibited by law. The Constitution guarantees to each other the right to have the property the right to own property, to own, use and dispose of them, either alone or jointly with other persons.

The principal meaning is the guarantee, under which the person can be deprived of its' property only by the decision of the court. The compulsory alienation of the properties for state needs can be made only on the basis of the preliminary and equal compensation.

According to the art. 36 of the Constitution the rights of possession, use and disposal of the land and other natural resources belong to the proprietor if it does not damage either the environment nor the rights and legal interests of any other persons.

As of Russia is a federal state, the Constitution distributes the state powers among the Russian Federation as a subject of law and its regions. The art.71 lists the exclusive powers of Russian Federation, art 72 - the common powers of Russian Federation and it's regions. As of exclusive powers of the regions - according to the art.73 the powers which have not been listed in the articles 71 and 72 of the Constitution belong exclusively to the regions of Russian Federation.

According to the point «e» of the art. 71 the power to development of the general lines of the federal policy in the scopes of the economical and environmental development of Russian Federation belongs exclusively to Russian Federation. According to this constitutional provision, the Russian Federation has the right to define the main directions of the development of the energy and fuel industry activity in these areas of federal bodies of state power, bodies of state power of subjects of the Federation, local authorities, legal entities and individual entrepreneurs.

The provision of the unified legal bases of the market also belongs to the Russian Federation serves to the realization of the principle of the united economical space. (point «j» of the art. 71 of the Constitution).

Logically, the Russian Federation has the exclusive powers for the development of civil legislation (point «0» of the art. 71 of the Constitution). Civil Code of Russian Federation ${ }^{3}$, is the only codified source of law which stipulates the rules concerning the Contract Law, Land Law, Property Law, Corporate Law and of course the bases of the legal position of the entities with foreign investments and foreign legal persons (and other organizations). Russian private law differs much from these of Europe and for example Ukraine - private law norms are unified in the Civil Code. The Commercial Code exists only in de lege ferenda proposals of some commercial law scholars 4 .

Foreign investors are to pay taxes under the national law of Russia. The federal taxes can be stipulated only by federal powers ( point «Z» of the art. 71 of the Constitution).

Nevertheless the fuel and energy investment sector find himself in the joint regulation of the Russian Federation and it's regions.

For instance the art. 72 brings to the joint regulation the relationships in the scope of subsoil proprietor powers (possession, use and (point «V»); delimitation of state property (point «g»); the use of the natural resources, the environment protection and the ecological security (point «d»).

As reflected in the Constitution co-management due to the fact that everything connected with the territory, its use and protection directly affects not only the interests of each individual member of the Federation, but the whole of the Federation as a whole ${ }^{5}$.

The Constitution carries out such a distinction, identifying objects jurisdiction of the Russian Federation (Art. 71), the joint jurisdiction of the Russian Federation and its members (Art. 72), as well as the completeness of the government (i.e. the authority) of the subjects of the Russian Federation, which they have outside the jurisdiction of the Russian Federation and the powers of the Russian Federation on joint jurisdiction (Art. 73).

Art. 72 (Part 1) of the Constitution considers the issues of ownership, use and disposal of land, subsoil, water and other natural resources (point «c»), division of state property (point «d»), natural resources (paragraph «d»), and forest legislation (point «k») under the joint jurisdiction of the Russian Federation and its subjects.

Art. 76 of the Constitution establishes that the joint regulation of the Russian Federation and it's regions can be issued by federal laws and in accordance with, the laws and other normative legal acts of the Russian Federation (Part 2), the federal laws and other normative legal acts of the Russian Federation may not contradict the federal laws adopted by the issues of competence of the Russian Federation, as well as the joint jurisdiction of the Russian Federation and its

\footnotetext{
${ }^{3}$ The Civil Code of Russian Federation (first part) of 30.11.1994 №51-FZ // Collected Legislation of the Russian Federation, 05.12.1994, №32, art. 3301 (last amended 22.10.2014); The Civil Code of Russian Federation (second part) of 26.01.1996 №14-FZ // Collected Legislation of the Russian Federation, 29.01.1996, №5, art. 410 ( last amended 31/ 12.2014); The Civil Code of Russian Federation (third part) of 26.11.2001 №146-FZ // Collected Legislation of the Russian Federation, 03.12.2001, №49, art. 4552 (last amended 05.05.2014)

${ }^{4}$ Makovskij A.L. On the Codification of Civil Law (1922 - 2006). C. 179 - 181; loffe O.S. On the economy law (Theory \& practice) // Grazhdanskoe zakonodatelstvo: Articles. Commentaries. Practice / Almaty, 2004. Issue. 20. p. 46 - 51.

${ }^{5}$ Commentary to the Constitution of RF. - M., BEK. 1996. - P. 317.
} 
subjects (part 5).

Consequently, the Constitution shall distinguish rule-making power of the federal lawmakers and legislators of the Russian Federation on issues of joint management. Moreover, within the meaning of Art. s 72 and 76 (parts 2 and 5) of the Constitution to the publication of the federal law on a particular subject is the subject of joint jurisdiction of the Russian Federation shall have the right to adopt its own law and other regulations. But after the publication of the federal law, such acts must be brought into compliance with federal law.

Federal law as a normative legal act of the general operation of regulating certain issues (objects) of a joint reference, defines the rights and obligations of the parties involved, including the powers of the government, and thus performs separation of powers.

From art. 11 (part 3), 72 (points «c», «d», «e» and «c» of Part 1), 76 (parts 2 and 5) and 94 of the Constitution follows that the Federal Assembly of the Russian Federation shall be entitled to legal regulation of issues related to the joint jurisdiction, to determine the appropriate specific powers and authorities of the government of the Russian Federation and the bodies of state power of subjects of the Russian Federation.

In this case, however, must be complied with the requirements of the Constitution, including its art. s 9 and 36 , relating to the ownership of natural resources and their use"6.

Concluding statement of the issue of the constitutional foundations of the foreign investment in the Russian energy industry, we note that by virtue of the Constitution adopted the preamble based on the responsibility for their country to present and future generations, aiming to ensure the well-being and prosperity of Russia.

For instance, according to the art. 1.2 The Law of Russian Federation «On the subsoil» of 21 February 1992 №2395-I $\mathrm{I}^{7}$ (hereinafter - «Law on Subsoil») the subsoil on the territory of Russian Federation, including the subsoil space and the mineral, energy and other resources are of state property.

In 2014 the Law on Subsoil has changed six times by the Federal laws of 23.06.2014 N 171-FZ, of 21.07.2014 N 260-FZ, of 21.07.2014 N 261-FZ, of 24.11.2014 N 366-FZ, of 29.12.2014 N 459-FZ, and of 31.12.2014 N 499-FZ.

The scope of this Law has expanded to geological survey, use and protection of the waters extracted from the subsoil parcels with hydrocarbons and waters used by the subsoil user for it's own needs (Preamble of the Law on Subsoil in the version of the Federal law of 21.07.2014 N 261-FZ).

The subsoil parcels with subsoil waters used for the aims of drinking water supply or for the aims of agricultural installations if the level of the extraction does not exceed $500 \mathrm{~m}^{3}$ per day are defines expressively as the local subsoil parcels (point 3 art.2.3 of the Law on Subsoil in the version of the Federal law of 29.12.2014 N 459-FZ).

The procedure of the water placement in the subsoil can be established by the federal executive body in the subsoil use (point 22 of the art.3 of the Law on Subsoil in the version of the Federal law of 21.07.2014 N 261-FZ)

The subsoil parcels can be granted for use in the form of the water placement for the needs of the subsoil user (point 3 art. 6 of the Law on Subsoil in the version of the Federal law of 21.07.2014 N 261-FZ).

The mining (geological survey and extraction) being operated by the legal entity under the control of the foreign investors or by the foreign investor itself can be executed during the geological studying of these parcels or after it (point 6 art. 6 of the Law on Subsoil in the version of the Federal law of 29.12.2014 N 459-FZ). Earlier provision stipulated the rule under which this procedure can be initiated only after the geological studying of these parcels.

Federal law 29.12.2014 N 459-FZ has added the Law on Subsoil by the art. 7.1. which is dedicated to the procedure of the technical corrections of the mining licenses.

According to the new version of the art. 18 of the Federal Law of 29.12.2014 N 459-FZ the geological survey of the subsoil waters and the non-extraction mining activity have become one of the legal bases for granting the permissions to subsoil parcel.

The new version of the art.19 of the Law on Subsoil (of the Federal Law of 29.12.2014 N 459-FZ) has expanded the right of the land parcel proprietor (the tenant, the owner of other land title under Russian law) to the subsoil to the extraction of the waters for its own (non-commercial needs) if the level of the extraction will not exceed $100 \mathrm{~m}^{3}$. The land parcel proprietor (the tenant, the owner of other land title) can extract subsoil waters without any mining license (permission).

The Federal Law of 21.07.2014 N 261-FZ has added point 8 to the art.22 of the Law on Subsoil. According to it the user of the subsoil parcel can use wastes of mining activity for the liquidation of the results of mining activity.

Point 12 item 2 of the art. 22 obliged the user of the subsoil parcel to exclude the negative influence to the

${ }^{6}$ paragraph 4 Of the Constitutional Court Resolution of 9 January 1998 2. № 1-П «On the question of the examination of the compliance of the Forestry Code of Russia with the provisions of the Constitution of Russian Federation».

${ }^{7}$ Collected Legislation of the Russian Federation, 06.03.1995, №10, art.823 (07.05.2013). 
environment at the disposal of water supplies.

Art.25.1 of the Law on Subsoil in the version of Federal Law of 31.12.2014 N 499-FZ which regulates the procedure of granting land parcels for mining narrowed it's scope to the land parcels which are in the state \& municipal property.

Federal Law of 31.12.2014 N 499-FZ has added the art.25.2 to the Law on Subsoil The result is the procedure of land confiscation for the aims of mining was unified - the new order is a blanket norm, which points to the civil legislation and land law.

The new version of the art 40 of the Law on Subsoil minimum (start) single payments for subsoil use for surveying and extracting of the oil and (or) gas condensate should be minimum $5 \%$ of the tax for average extracting of mineral resources (Federal Law of 24.11.2014 N 366-FZ).

Under provisions of the part 6 of the article 40 of the Law on Subsoil The Federal Government can place the cases and procedures for paying of such single payments partially.

According to the art. 9 Federal law «On the production sharing contracts» of 30 December 1995 №225-FZ ${ }^{8}$ ((hereinafter - «Law on PSA `s») the part of the extracted production which is under the terms of the contract the share of the investor, belongs to him as a property.

Art. 7 of the Law on PSA's provides among other terms of the works of the investor the following:

- measures, directed to prevention of the influence of such works to the environment and the restitution of the results of such works;

- the insurance of the responsibility for compensation of the losses in the case of accidents that resulted in harmful effects on the environment;

- liquidation of all the installations, structures and other properties after the finalization of the works under the above mentioned agreement, and the purification of the territory of such works.

Constitutional provisions are detailed in the special norms of the legislation. The, art. 1 of the Law «On the subsoil» defines that, the legislation of Russian Federation on the subsoil is based on the Constitution of Russia and consists of the Law above mentioned and other federal laws and normative acts which based on the Constitution of Russian Federation and consists of the mentioned Law, other federal laws and normative acts adopted in accordance with it, and the laws and normative acts of the regions of Russia. The laws and normative acts of the regions of Russia can not contradict the Law «On the subsoil».

In the case of such a contradiction appears, only the norms of the Law «On the subsoil» and other federal laws can be seen as norms in force.

Changes to the provisions of the Federal law «On the foreign investments in Russian Federation» of 9 July 1999 №160-FZ, made by Federal laws on 03.02.2014 N 12-FZ, on 05.05.2014 N 106-FZ. The scope of the relations regulated by this law was narrowed - it's provisions should not regulate the creation and termination of the representative offices of foreign banks (and other credit organizations) (art.1 of this Law).

According to the new version of the point 3 art.4 the foreign legal entity can act in the territory of Russia through the branch (philial) or the representative office (predstavitelstvo) from the date of it's accreditation if the federal laws have not pointed out the other rule.

Art. 11 of the recent version of the Federal law above mentioned added the right to transfer from the Russian Federation money received from the termination of the branch (earlier version restricted this right to transfer money received from the liquidation of the branch.

Federal Law «On the PSA's» regulates the relationships in the scope of conclusion, executing and cessation of this civil law contracts and defines the principal conditions of such contracts.

The relationships concerning survey, geological survey and the extraction of the minerals and the sharing of the oil extracted from the subsoil parcels, also the mentioned federal law regulates it's transportation its transportation, handling, storage, processing, use, enjoyment or disposal otherwise regulated directly by agreement.

Production Sharing Agreement is classified as civil contracts (paragraph 2 of paragraph 3 of Art. 1 of the Act).

This law provides the criteria for inclusion in the category of subsoil plots, the right to use which may be granted under the PSA - lack of exploration, development and mining operations under a license regime provided for by the Law «On Subsoil».

There is a possibility to change the license conditions for using a particular oilfield mode production sharing agreement (par.3 Art. 2 paragraph 4 of the Federal Law «On the PSA`s»). Parties to the production sharing agreement may be the Russian Federation and investors.

${ }^{8}$ Collected Legislation of the Russian Federation, 01.01.1996, №1, art. 18 (19.07.2011). 
Investors may be only legal entities and based on agreements on joint activities without forming a legal entity associations of legal entities engaged invest their own money borrowed or raised (property and (or) property rights) in prospecting, exploration and extraction of mineral resources and are subsoil users to the terms of the agreement.

Term of the agreement is determined by the parties. In order to coordinate the execution of work by the parties should be provided for the establishment of the steering committee, composed of an equal number of representatives from the government and the investor. The number of members, the rights and duties of such a committee, and its implementation is determined by the agreement.

The procedure for appointment of representatives of the state, their powers, and the procedure of preparation and decision making on behalf of the State set in the Russian Federation Government Decree «On the appointment and activities of state representatives in the governing committees set up in accordance with the terms of the production sharing agreements» of 14 March 2006 № $133^{9}$.

The provisions of paragraph 1 of art. 8 of the Federal Law «On the PSA s» is defined by the approximate order of production sharing between the parties. Changing the way of production sharing is not allowed.

Paragraph 2 of Art. 17 of the Federal Law «On the PSA's» provides for the reservation of the stability of the investment regime for the investor. If during the term of the agreement by the legislation of the Russian Federation, Russian Federation and the legal acts of local self-government will set the standards, deteriorating business performance of the investor under the agreement, the text of the agreement have been changed to ensure investor commercial results, to which he was entitled to expect at the conclusion of the production sharing agreement.

Attention is drawn to limit the application of this clause in case of changes in the laws of the Russian Federation and it subjects. Thus, by-laws, worsening terms of investment, are not grounds for a corresponding change in the agreements.

This law was the first act providing for the possibility of failure of the Russian Federation on jurisdictional immunities of the agreements concluded with foreign citizens and foreign legal persons (Art. 23 of the mentioned Law) ${ }^{10}$.

It should be noted that the bilateral agreements between the Government of the Russian Federation and foreign governments on the promotion and reciprocal protection of investments are to be concluded on the basis of the Model Agreement, approved by the, Russian Federation Government Decree of 9 June 2001 №45611.

Formed for the early 90 -ies of the last century investment legislation did not provide any significant features of foreign investment in the oil and gas industry.

On April 29, 2008 the Federal Law «On Foreign Investments in Business Entities of Strategic Importance for National Defense and State Security» №57-FZ ${ }^{12}$ (hereinafter - Federal Law №57-FZ) established a series of restrictions on foreign investors, as well as groups of persons to which the foreign investor.

These exemptions concerned two aspects of foreign investors:

1) their participation in the charter capital of business entities of strategic importance for national defense and national security;

2) they commit transactions that establish their control of such business entities.

In the year 2014 this Federal law has undergone the following changes under federal laws on 03.02.2014 N 15-FZ, on 12.03.2014 N 29-FZ, and on 04.11.2014 N 343-FZ. The art.1 has changed the «control under entities» criteria to the rights of the acquirement, possession and use of the properties of such entities. So if the foreign investor under this law doesn't acquire any part of proprietors rights, his investments are not the subject to the provisions of this law.

Part 3 art.3 of this Federal Law has added to the legal definition of the position «agreement» by the «deals in oral and in written form directed to right of votation on the entity of strategic importance and to other opportunity to define the resolutions of the bodies of such an entity including the commercial activity»».

Tax and revenues system, paid by the foreign investors in Russia is stipulated in the Tax Code of Russia ${ }^{13}$.

In addition to the taxes which are to be paid under the common tax regime (corporate income tax, the tax on mineral extraction activities, etc.), some foreign investors can become the taxpayers of the special regime.

\footnotetext{
${ }^{9}$ Collected Legislation of the Russian Federation 20.03.2006, №12, art. 1304 (amended 19.07.2011).

${ }^{10}$ Despite widespread opinion, the waiver of the state immunity can be pronounced not only expressis verbis. For example the filing a counter-claim by the state or appearance of a representative of the state in court can be appraised as a waiver of state immunity.

${ }^{11}$ Government Decree of 9 June 2001 №456 «On the conclusion of agreements between the Government of the Russian Federation and foreign governments on the promotion and reciprocal protection of investments " / Collected Legislation of the Russian Federation. 2001. №25. Art. 2578.

${ }^{12}$ Collected Legislation of the Russian Federation 5.05.2008, N 18, art. 1940

${ }^{13}$ Tax code of Russia. Part 1. Collected Legislation of the Russian Federation № 31 om 03.08.1998, art. 3824, Part 2. Collected Legislation of the Russian Federation № 32 from 07.08.2000, art. 3340.
} 
For instance, foreign investors, participating in the production sharing agreement become the subjects of the special tax regime according to the Chapter 26.4 Tax Code of Russia « Taxation system of production-sharing agreements $»$.

The Federal law «On the Continental shelf of Russian Federation» of 30 November 1995№187-FZ ${ }^{14}$ has been changed by the Federal law 03.02.2014 N 15-FZ, and by the Federal Law 14.10.2014 N 307-FZ. According to the new provisions of this Law the new artificial islands, installations and structures constructed, the security zone made around this islands, installations and structures and it's removal as well has to be reported to the Ministry of Transport (earlier to the body defined by the President of Russia). The security zone's border is to be defined by the same body under the new provisions of law. According to the art.48 of the Federal law «On the Continental Shelf of Russian Federation» in the version of 14.10.2014 N 307-FZ the President and the Government are not obliged to legislate in the scope of the state control under artificial islands, installations and structures.

Federal law «On the concession agreements» от 21 July 2005 № 115-FZ15 regulates the relationships on the conclusion, signing, changing and ending the concession agreements, provides the guarantees of the rights and interests of the concession agreements been changed under the provisions of the Federal law of 28.06.2014 N 180-FZ and Federal law of 21.07.2014 N 265-FZ.

Under the provisions of that law under the concession agreement one party (the concessionaire) is obliged to create and (or) reconstruct at his own expense the real property defined in this agreement (hereinafter - the object of the concession agreement), the rights of the proprietor to this object belongs or will belong to the other party (concedent), to make activities using this object, and the concedent is obliged to provide the concessionaire the rights of possession and use of this object for the term mentioned in the concession agreement. Federal law of 21.07.2014 N 265-FZ renewed the provisions of the law, establishing the «joint tender agreement» the parties entered to, when the real property which is planning to be constructed or reconstructed will belong to the different public law entities. The above mentioned Federal law has also stipulated the obligatory terms of such an agreements.

The object's list of the concession according to the point 1 of the art. 4 of this Law has not been changed seriously under the Federal laws above mentioned. The significant changes took place on the procedure of the "granting" - the concedent is obliged to establish the list of the objects, which are planning to be transferred under the concession agreement and is obliged to place the appropriate information in the Internet. Also the new rules placed the priority of that plan to the privatization plan. According to the new provisions the concession agreements can mention several objects if they belong to heat supply, centralized hot water supply, cold water supply and (or) water disposal, provided the concessionaire's activity in realization of goods and services on the tariffs which are stipulated by the state bodies if such contract will not result to prevention, restriction, or to the elimination of the competition.

\section{References}

Constitution of Russian Federation // Adopted on the referendum of 12.12.1993 // Collected Legislation of the Russian Federation, 26.01.2009, №4, art.445.

Commentary to the Constitution of RF. - M., BEK. 1996.

Foreign Investment and Energy: issues of public and international legal regulation in the CIS: a monograph in two parts. / Editor R. Kurbanov. Moscow: 2011.

Gadzhiev G.A. The Constitutional principles of the market economy (the development of the basement of the civil law in the decisions of the Constitutional Court of Russian Federation) - M., 2002.

Makovskij A.L. On the Codification of Civil Law (1922 - 2006).

Ioffe O.S. On the economy law (Theory \& practice) // Grazhdanskoe zakonodatelstvo: Articles. Commentaries . Practice / Almaty, 2004. Issue. 20.

${ }^{14}$ Collected Legislation of the Russian Federation, 04.12.1995, №49, art.4694.

${ }^{15}$ Collected Legislation of the Russian Federation, 25.07.2005, №30 (ч. II), art. 3126. 